\title{
STUDI PEMBUATAN DODOL PISANG
}

\author{
Rifni Novitasari, S.Tp. MP \\ Dosen Teknologi Pangan FAPERTA UNISI \\ rifninovi@gmail.com
}

\begin{abstract}
Abstrak
Buah-buahan secara umum mudah mengalami kerusakan mekanis, fisiologis, kimiawi dan mikrobiologis apabila ditangani secara tidak tepat termasuk buah pisang. Akibatnya buah menjadi tidak segar dan kualitas buah itu sendiri menjadi turun yang mengakibatkan nilai jualnya menjadi rendah. Berbagai cara pengolahan buah pisang telah dikembangkan sehingga menjadikan berbagai produk dengan rasa yang bervariasi. Selain bertujuan untuk mengolah buah segar, pembuatan dodol buah pisang juga bertujuan menyelamatkan buah pisang yang cacad secara fisik dalam arti kata buah berukuran kecil dengan kulit buah yang jelek. Studi ini bertujuan untuk memberikan pengetahuan tentang bagaimana cara pengolahan dodol pisang yang tepat sehingga dihasilkan dodol pisang yang enak dengan penampilan yang menarik.
\end{abstract}

\section{PENDAHULUAN}

Pisang merupakan buah yang mempunyai kandungan gizi sangat baik, antara lain menyediakan energi dari karbohidrat cukup tinggi dibandingkan dengan buah-buahan lain. Pisang kaya mineral seperti kalium, magnesium, fosfor, besi, dan kalsium. Pisang juga mengandung vitamin, yaitu $\mathrm{C}, \mathrm{B}$ kompleks, B6, dan serotonin yang aktif sebagai neurotransmitter dalam kelancaran fungsi otak (Anonim, 2008).

Buah pisang banyak dihasilkan di Kabupaten Indragiri Hilir, yang produksinya meningkat dari tahun ke tahun. Produksi buah pisang pada tahun 2006 adalah sebesar 10.662 ton (Website Resmi Pemerintahan Riau, 2010), meningkat pada tahun 2007 menjadi 542,635 ton hingga tahun 2008 diketahui luas areal panen adalah seluas 293,67 Ha dengan total produksi 3.122,93 ton (Indragiri Hilir dalam Angka, 2010).

Buah-buahan secara umum mudah mengalami kerusakan mekanis, fisiologis, kimiawi dan mikrobiologis. Menurut Satuhu (1994), kerusakan buah tersebut dapat mencapai $30-\quad 50 \%$ tergantung jenis komoditinya.

Pemanfaatan buah pisang selama ini belum optimal masih terbatas sebagai buah konsumsi segar dan produk olahan tradisional baik dari buah masih mentah maupun dari buah yang sudah masak. Hal yang perlu diantisipasi adalah lonjakan produksi pada saat panen raya disentra-sentra produksi pisang sedangkan serapan pasar yang tidak berimbang menyebabkan banyaknya buah yang terbuang. Pisang terutama yang sudah matang, dapat sebagai salah satu jenis buah-buahan yang potensial sebagai penyedia energi dalam makanan dan minuman (pangan).

Pisang matang merupakan buah yang mudah busuk karena kadar airnya yang cukup tinggi. Selain itu ketika pisang masak maka teksturnya akan lembut dan umur simpanya sekitar 7-8 hari (Surendranathan, 2003). Selama pengangkutan yang kurang baik, akan terjadi benturan, dan kemudian terjadi pelepasan etilen dalam ruangan. Etilen akan menpercepat pematangan buah 
dalam pengangkutan sehingga membuatnya lebih cepat busuk sebelum mencapai tujuannya.

Seperti halnya kelapa, sebenarnya pohon pisang dapat diolah hampir dari seluruh bagian pohon tersebut. Pengolahan buah pisang merupakan salah satu cara untuk mempertahankan daya simpan, meningkatkan permintaan serta daya guna buah pisang adalah dengan mengolahnya menjadi berbagai macam produk olahan.

\section{Berdasarkan cara konsumsi, pisang dikelompokkan dalam dua golongan, yaitu banana dan plantain. Banana adalah pisang yang lebih sering dikonsumsi dalam bentuk segar atau buahnya setelah matang, contohnya pisang ambon, susu, raja, seribu, dan sunripe. Plantain adalah pisang yang dikonsumsi setelah diolah seperti digoreng, direbus,dibakar, atau dikolak, seperti pisang kepok, siam, kapas, tanduk, dan uli.Buah pisang mempunyai kandungan gizi sangat baik, antara lain menyediakan energi cukup tinggi dibandingkan dengan buah-buahan lain.}

Pemanfaatan tanaman pisang cukup beragam, mulai dari akar, buah, kulit buah, bonggol, batang pisang, bunga dan daunnya dapat digunakan sebagai obat (Admin, 2006). Selain itu batang pisang dapat digunakan untuk berbagai keperluan, antara lain sebagai tudung penahan hujan maupun panas bagi bibit yang baru ditanam. Pelepah batang pisang yang telah dikeringkan dapat digunakan sebagai bahan anyaman kerajinan. Sebelum ada pembungkus dari bahan plastik, daun pisang mempunyai banyak kegunaan antara lain sebagai pembungkus makanan jadi yang siap dimakan, sebagai pembungkus makanan yang diawetkan misalnya lepet ketan, tempe, dan lain-lain. Daun pisang yang masih hijau digunakan sebagai makanan ternak. Selain dimakan dalam bentuk segar, buah pisang dapat diolah menjadi pisang goreng, keripik pisang, sale pisang, tepung pisang, dan saus pisang. Bunga pisang yang berupa otong jantung, pada jenis-jenis tertentu dapat menjadi bahan sayur (Suhardiman, 1997).

Berkembangnya teknologi pengolahan pangan berdampak makin banyaknya olahan buah pisang yang sering kita temui dipasaran, antara lain adalah : dodol pisang

\section{TINJAUAN PUSTAKA}

\section{Botani Pisang (Musa Sp)}

Pisang berasal dari bahasa Arab yaitu maus dan menurut Linnaeus termasuk keluarga Musaceae (Satuhu dan Supriyadi, 1999). Pisang barangan merupakan pisang yang paling populer di Sumatera Utara (Nuswamarhaeni, 1999). Indonesia merupakan salah satu negara penghasil tanaman pisang dengan tingkat keragaman yang sangat tinggi dan tersebar di seluruh daerah di Indonesia. Pisang Barangan adalah salah satu jenis pisang yang sangat digemari oleh konsumen meskipun harganya lebih mahal dibandingkan jenis lainnya (Nainggolan, 2002 cit Wahyudi, 2004).

Adapun botani tanaman pisang adalah sebagai berikut: tumbuhan seperti pohon, tinggi 2-9 $\mathrm{m}$; batang pendek dalam tanah yang disebut Corm; mempunyai kuncup-kuncup tunas yang akhirnya berkembang menjadi anakan. Akar liar (adventif) tumbuh menyebar secara lateral, dapat mencapai panjang 4$5 \mathrm{~m}$. Batang yang di atas permukaan tanah adalah batang semu yang merupakan kumpulan dari pelepah daun yang berdaging, membentuk suatu bentuk silindris dengan diameter 20-50 $\mathrm{cm}$. Daun baru yang terbentuk tumbuh dari batang semu. Helai daun berbentuk oblong yang besar dengan panjang 150- 
$400 \mathrm{~cm}$ dengan lebar 70-100 cm. Bila bunga majemuk telah terbentuk di ujung batang semu, maka pembentukan helai daun baru akan berhenti. Bunga majemuk terkumpul menjadi beberapa kelompok (sisir) dan setiap kelompok didukung oleh daun penumpu yang besar, berwarna merah dan di dalamnya terdapat dua baris bunga. Keseluruhan kelompok bunga ini bersatu dalam bentuk seperti jantung, sehingga disebut sebagai jantung pisang. Daun penumpu dari setiap kelompok bunga akan luruh setelah terjadinya proses perkembangan buah (Sudarnadi, 1996).

Menurut Steenis (2003), kedudukan pisang barangan dalam taksonomi adalah:

Kingdom : Plantae

Divisio : Spermatophyta

Sub Divisio : Angiospermae

Kelas : Monocotyledoneae

Ordo : Zingiberales

Famili : Musaceae

Genus : Musa

Spesies : Musa acuminata L.

Tanaman pisang termasuk tanaman iklim tropis basah yang mudah didapatkan di Indonesia, tanaman ini tahan hidup di musim kemarau, mampu tumbuh dan berproduksi baik pada berbagai jenis tanah pada ketinggian tempat antara 0-1000 $\mathrm{m}$ di atas permukaan laut. Tanaman pisang mudah tumbuh di berbagai tempat sehingga penanaman yang dilakukan oleh petani belum teratur dan sering dicampur dengan tanaman lainnya. Selain itu pemeliharaan tanaman pisang belum dilakukan secara intensif, sehingga produksi dan mutu buah yang dihasilkan masih rendah (Warda dan Hutagalung, 1994).
Di Indonesia tanaman pisang banyak dibudidayakan karena disamping pertimbangan nilai gizi dan harganya murah, tanaman pisang mudah untuk tumbuh. Hampir setiap tempat dapat dengan mudah ditemukan tanaman pisang. Pusat produksi pisang di Jawa Barat adalah Cianjur, Sukabumi, dan daerah sekitar Cirebon. Tidak diketahui dengan pasti luas perkebunan pisang di Indonesia. Walaupun demikian Indonesia termasuk salah satu negara tropika yang memasok pisang segar atau kering ke Jepang, Hongkong, Cina, Singapura, Arab, Australia, Negeri Belanda, Amerika Serikat, dan Perancis. Nilai ekspor tertinggi pada tahun 1997 adalah ke Cina (Sunarjono, 2004).

Jenis pisang dibagi menjadi empat: 1. Pisang yang dimakan buahnya tanpa dimasak, yaitu M. paradisiaca var. sapientum, $M$. nana atau disebut juga $M$. cavendishii, dan $M$. sinensis. Misalnya, pisang ambon, susu, raja, cavendish, dan barangan, 2. Pisang yang dimakan setelah buahnya dimasak, yaitu $M$. paradisiaca forma typica atau disebut juga $M$. paradisiaca normalis. Misalnya, pisang nangka, tanduk, dan kepok, 3. Pisang berbiji, yaitu $M$. brachycarpa, yang di Indonesia dimanfaatkan daunnya. Misalnya, pisang batu dan klutuk dan 4. Pisang yang diambil seratnya, misalnya pisang manila (abaca).

Pisang termasuk tanaman yang mudah tumbuh di sembarang tempat. Namun, agar produktivitasnya optimum, sebaiknya pisang ditanam sesuai dengan syarat agronomi dan agroklimat tanamannya, yaitu dataran rendah tropika basah dengan ketinggian 100$700 \mathrm{~m}$ dpl dan suhu udara $22-32^{\circ} \mathrm{C}$, tidak terdapat angin kencang, subur, dan terutama harus ada sumber pengairan saat musim kemarau panjang. Di daerah 
beriklim basah dengan curah hujan merata sepanjang tahun (2.000-3.000 $\mathrm{mm} /$ tahun), ketersediaan sumber air menjadi kurang penting bagi tanaman pisang (Sunarjono, 2004).

Selain syarat tersebut, pada tanah tandus atau marginal (karena banyak erosi, bercadas, atau berpasir kuarsa), sangat diperlukan pemberian bahan organik (pupuk kandang atau kompos) yang tinggi (40-60 kg/tanaman). Kemiringan tanah pun perlu diperhatikan. Daerah dengan agak miring (kemiringan kurang dari 10\%) sangat baik sebagai kebun pisang. Hal ini disebabkan penutasan (draenase) air lebih mudah dibanding lahan datar (Sunarjono, 2004).

\section{Komposisi Kimia dan Nilai Gizi Buah Pisang}

Buah pisang mengandungenergi, protein, lemak dan berbagai vitamin dan mineral. Adapun komposisi kimia dan zat gizi buah pisang tabel 1 berikut ini :

Tabel 1. Kandungan gizi buah pisang per 100 gram bahan

\begin{tabular}{|l|r|}
\hline \multicolumn{1}{|c|}{ Senyawa } & Kompetensi \\
\hline Air (gram) & 75.00 \\
Energi (K) & 88.00 \\
Karbohidrat (gram) & 23.00 \\
Protein (gram) & 1.20 \\
Lemak (gram) & 0.20 \\
Ca (mg) & 8.00 \\
P (mg) & 28.00 \\
Fe (mg) & 0.60 \\
Vitamin A & 439.00 \\
Vitamin B-1 (mg) & 0.04 \\
Vitamin C (mg) & 78.00 \\
\hline
\end{tabular}

Menurut Prabawati, $\mathrm{S}$ et al (2008), buah pisang mempunyai kandungan gizi yang baik, antara lain menyediakan energi yang cukup tinggi dibandingkan dengan buah-buahan yang lain. Pisang kaya mineral seperti kalium, magnesium, besi, fosfor dan kalsium, juga mengandung vitamin $\mathrm{B}$, B6 dan C serta serotonin yang aktif sebagai neutransmitter dalam kelancaran fungsi otak. Nilai energi pisang rata-rata 136 kalori untuk setiap 100 g sedangkan buah apel hanya 54 kalori. Karbohidrat pada pisang memberikan energi lebih cepat dari nasi dan biskuit, sehingga para atlet banyak mengonsumsi pisang saat jeda untuk cadangan energi. Karbohidrat pada pisang merupakan komplek tingkat sedang dan tersedia secara bertahap,sehingga dapat menyediakan energi dalam waktu yang tidak terlalu cepat.

Bila dibandingkan dengan jenis makanan lainnya, mineral pisang khususnya besi dapat seluruhnya diserap oleh tubuh. Kandungan vitamin A tertinggi pada buah pisang raja bulu dicirikan dengan warna daging buah kuning kemerahan. Hanya buah pisang emas dan raja sere yang memiliki bagian yang dapat dimakan sebesar $85 \%$ karena kulit buahnya yang tipis. Tabel 2 berikut memberian perbandingan nilai gizi beberapa jenis pisang. 
Tabel 2. Kandungan nilai gizi beberapa varietas pisang di Indonesia

\begin{tabular}{|l|r|r|r|r|r|r|}
\hline $\begin{array}{c}\text { Varietas } \\
\text { pisang }\end{array}$ & $\begin{array}{c}\text { Kalori } \\
\text { (Kalori) }\end{array}$ & $\begin{array}{c}\text { Kabohidrat } \\
(\%)\end{array}$ & \multicolumn{1}{c|}{$\begin{array}{c}\text { Vitamin C } \\
(\mathrm{mg})\end{array}$} & \multicolumn{1}{c|}{$\begin{array}{c}\text { Vitamin A } \\
(\mathrm{SI})\end{array}$} & \multicolumn{1}{c|}{$\begin{array}{c}\text { Air } \\
(\mathrm{gram})\end{array}$} & $\begin{array}{c}\text { Bagian yg dpt } \\
\text { dimakan (\%) }\end{array}$ \\
\hline & & & & & & \\
Ambon & 99.00 & 25.80 & 3.00 & 140.00 & 72.00 & 75.00 \\
Angleng & 68.00 & 17.20 & 6.00 & 76.00 & 80.30 & 75.00 \\
Lampung & 99.00 & 25.60 & 4.00 & 61.80 & 72.10 & 75.00 \\
Emas & 127.00 & 33.60 & 2.00 & 79.00 & 4.20 & 85.00 \\
Raja bulu & 120.00 & 31.80 & 10.00 & 950.00 & 65.80 & 70.00 \\
Raja sere & 118.00 & 31.10 & 4.00 & 112.00 & 67.00 & 85.00 \\
Uli & 146.00 & 38.20 & 75.00 & 75.00 & 59.10 & 75.00 \\
\hline
\end{tabular}

Sumber : Anonymous, 1992

\section{Dodol Pisang}

Dodol adalah makanan berupa gel yang terbuat dari campuran bahan beras pati, gula dan bahan pengisi lainnya seperti buah dan rumput laut. Dodol tergolong makanan semi basah dengan kadar gula tinggi sehingga dapat disimpan agak lama (1-3 bulan). Menurut Astawan (1991), dodol merupakan sejenis makanan yang mempunyai sifat agak basah sehingga dapat langsung dimakan tanpa dibasahkan terlebih dahulu (rehidrasi) dan juga cukup kering sehingga cukup stabil selama penyimpanan.

Pembuatan makanan ini tidak sulit dan dapat dilakukan dengan menggunakan alat-alat yang biasa terdapat pada rumah tangga sehingga dapat menjadi industi rumah tangga.

Dodol merupakan makanan tradisional yang popular di beberapa daerah di Indonesia, dapat diolah dari buah-buahan dicampur dengan gula atau diberi tambahan bahan lain seperti tepung beras, tepung ketan, tepung tapioka,tepung hunkwe, dan bahan tambahan pangan lainnya.

Bahan baku pisang yang akan diolah menjadi dodol harus dipilih yang matang penuh. Semua jenis pisang dapat diolah menjadi dodol pisang, tetapi yang paling enak adalah dodol yang diolah dari pisang ambon karena memiliki rasa enak dan aromanya kuat. Pisang yang akan diolah harus dipilih yang telah matang sempurna. Pisang mentah juga dapat menjadi bahan untuk dodol,dengan cara dibuat menjadi tape pisang lebih dulu.Untuk menghasilkan dodol pisang yang enak, dapat digunakan perbandingan bahan: pisang matang 1,5 $\mathrm{kg}$, gula merah $1 \mathrm{~kg}$, tepung ketan $250 \mathrm{~g}$, santan kental 1 liter dan garam $10 \mathrm{~g}$. Dalam pemasakannya, sebaiknya digunakan api sedang dan dilakukan pengadukan terus menerus. Adapun syarat mutu dodol secara umum ditampilkan sebagai berikut: 
Tabel 2. Syarat Mutu Dodol, SNI No. 01-2986-1992

\begin{tabular}{|c|c|c|}
\hline Kandungan Gizi & Satuan & Jumlah \\
\hline Keadaan (aroma, rasa dan warna ) & - & Normal / khas dodol \\
\hline Kadar Air & $\% \mathrm{~b} / \mathrm{b}$ & Maks $20 \%$ \\
\hline $\mathrm{Abu}$ & $\% \mathrm{~b} / \mathrm{b}$ & Maks $1,5 \%$ \\
\hline $\begin{array}{l}\text { Gula yang dihitung sebagai } \\
\text { sakarosa }\end{array}$ & $\% \mathrm{~b} / \mathrm{b}$ & Maks $45 \%$ \\
\hline Protein $(\mathrm{N} x$ 6,23) & $\% \mathrm{~b} / \mathrm{b}$ & Min 3\% \\
\hline Lemak & $\% \mathrm{~b} / \mathrm{b}$ & Min 3\% \\
\hline Serat Kasar & $\% \mathrm{~b} / \mathrm{b}$ & Maks $1,0 \%$ \\
\hline Bahan Tambahan Makanan & - & $\begin{array}{l}\text { Sesuai dg SNI 0222-M dan } \\
\text { Peraturan } \\
\text { MenKes No. } \\
\text { 722/MenKes/Per/Lx/88 }\end{array}$ \\
\hline Pemanis Buatan & - & Tidak nyata \\
\hline Cemaran Logam : & & \\
\hline * Timbal $(\mathrm{Pb})$ & $\mathrm{Mg} / \mathrm{Kg}$ & Maks 1,0 \\
\hline * Tembaga & $\mathrm{Mg} / \mathrm{Kg}$ & Maks 10,0 \\
\hline * Seng & $\mathrm{Mg} / \mathrm{Kg}$ & Maks 40,0 \\
\hline * Arsen & $\mathrm{Mg} / \mathrm{Kg}$ & Maks 50,5 \\
\hline Cemaran Mikroba & & \\
\hline * Angka Lempeng Total & Koloni & Maks $5 \times 10^{2}$ \\
\hline$*$ E. coli & $\mathrm{APM} / \mathrm{g}$ & 3 \\
\hline * Kapang dan Khamir & Koloni/g & Maks $1 \times 10^{2}$ \\
\hline
\end{tabular}

\section{BAHAN DAN METODA}

Bahan yang digunakan : Pisang nangka yang telah matang konsumsi, dan daging lunak (1 kg), gula pasir putih bersih. $(0,25 \mathrm{~kg})$. yang ini digiling sampai halus, gula merah (100 gram) yang digiling sampai halus, garam dapur halus dan putih bersih (10 gram), tepung ketan (50 gram), santan kental (450 ml), natrium benzoat ( 1 gram), lemak sapi secukupnya (lemak padat sapi dibersihkan dari jaringan daging, dan dipotong kecil-kecil. Setelah itu potongan lemak dimasak dalam panci atau wajan sampai mencair. Setelah mencair, lemak cair panas ini disaring dengan kain saring secara cepat. Setelah itu, lemak dipanaskan lagi sambil diaduk-aduk. Busa yang timbul dibuang).

Alat yang digunakan : wajan, penggilingan (blender atau lumpang), cetakan, alat pengering.

Langkah - langkah pembuatan dodol pisang :

1. Pembuatan adonan dodol. Pisang dikupas, kemudian digiling sampai halus. Setelah itu ditambahkan gula pasir, gula merah, tepung ketan, santan kental dan natrium benzoat. Campuran ini diaduk sampai rata. Campuran ini disebut dengan adonan dodol.

2. Pemasakan adonan. Adonan dimasak di dalam wajan sambil 
diaduk. Pengadukan dilakukan sampai adonan menjadi liat, berminyak dan tidak lengket. Hasil pemasakan ini disebut dengan adonan dodol masak.

3. Pencetakan. Adonan dodol masak diangkat dari wajan, kemudian dimasukkan ke dalam cetakan berbentuk baki dengan ketinggian 1$2 \mathrm{~cm}$. Adonan ditekan-tekan agar padat dan rata. Sebelum adonan dimasukkan, permukaan dalam baki dialasi dengan plastik atau daun pisang.

4. Penjemuran. Adonan dodol di dalam cetakan dijemur sampai agak kering atau dikeringkan dengan alat pengering

5. Pemotongan dan pelapisan dengan lemak. Dodol yang telah mengeras dipotong-potong, kemudian dicelupkan ke dalam lemak sapi yang sedang mencair, dan segera diangkat. Dodol ini dibiarkan beberapa saat sampai lemak pada permukaannya mengeras.

6. Pengemasan. Potongan-potongan dodol dibungkus dengan kertas minyak, kertas kue atau plastik. Setelah itu, dodol dikemas di dalam kantong plastik.

\section{HASIL DAN PEMBAHASAN}

Pada studi pembuatan dodol ini diperoleh hasil dodol pisang dengan aroma, rasa dan tekstur yang disukai secara organoleptik, dengan kadar air $18,5 \%$.

Tekstur dodol pisang yang dihasilkan memiliki tekstur yang kalis dan tidak lengket, karena pada dasarnya bahan baku pembuatan dodol selain buah pisang itu sendiri, kita menggunakan tepung ketan. Tepung ketan merupakan tepung yang kadar amilopektinnya paling tinggi sehingga produk yang dihasilkan berupa produk yang elastis dan kalis karena ditambahkan juga santan yang mengandung lemak dan minyak. Sedangkan bagian luar dodol yang mengkilap disebabkan adanya pelapisan gula atau glazing.

Gula pasir yang dipergunakan berfungsi sebagai penambah rasa manis dan legit dodol, terutama bila dodol yang digunakan memiliki rasa asam atau kurang manis seperti buah pisang nangka, tetapi bila buah pisang yang dipergunakan sudah manis (seperti buah pisang ambon atau pisang raja) maka penambahan gula bisa dikurangi.

Rasa dodol pisang yang lezat yang diminati panelis dan tekstur yang kalis tidak lepas dari peranan santan yang ditambahkan pada proses pembuatan dodol pisang ini. Satuhu (1994) cit Rachmi Hatta (2012) menyatakan bahwa santan yang dipergunakan dalam pembuatan dodol terdiri dari santan kental dan santan encer. Fungsi santan secara umum adalah sebagi penambah cita rasa dan aroma. Santan kental penting dalam pembuatan dodol karena mengandung lemak sehingga dihasilkan dodol yang mempunyai cita rasa yang lezat dan membentuk tekstur yang kalis. Sedangkan santan encer berfungsi untuk mencairkan tepung, sehingga terbentuk adonan untuk melarutkan gula.

Hal ini juga diungkapkan oleh Sundari (1984) yang menyatakan bahwa santan dalam pengolahan makanan berfungsi sebagai media penghantar panas pada waktu pemasakan, menaikkan kelezatan (polabilitas) makanan dengan mempertinggi flavor, meminyaki makanan serta peralatan sehingga adonan tidak mudah lengket pada alat, dan mempertinggi keempukan dodol. Penambahan ini akan 
memperbaiki kenampakan dodol dan lebih mengkilap.

Kadar air dari dodol pisang yang dihasilkan adalah sebesar 18,5\% . Hal ini berkaitan dengan sifat amilopektin dari tepung ketan yang digunakan. Sifat molekul amilopektin ini dapat memperkuat pengikatan air dengan baik sehingga dihasilkan kadar air yang disyaratkan pada proses pembuatan dodol. Menurut Satuhu (1994) cit Rachmi Hatta (2012) tepung beras ketan berasal dari beras ketan yang digiling, dimana agar mendapatkan hasil yang baik maka dipilih beras ketan yang berwarna putih, kering dan halus, tidak berbau apek, baru dan halus yang berfungsi untuk merekatkan adonan. Lebih lanjut diuraikan oleh Astawan dan Wahyuni (1991) bahwa dodol termasuk jenis makanan setengah basah (Intermediate Moisture Food) yang mempunyai kadar air $10-40 \%$; Aw $0,70-0,85$; tekstur lunak; mempunyai sifat elastis, dapat langsung dimakan, tidak memerlukan proses pendinginan dan tahan lama selama penyimpanan.

Winarno (2004) menambahkan bahwa pati memiliki dua fraksi utama yaitu amilosa dan amilopektin. Proses pemanasan di samping terjadi pembengkakan granula pati juga diikuti dengan peningkatan viskositas. Semakin besar pembengkakan granula, semakin besar viskositas. setelah pembengkakan maksimum, dan pemanasan tetap dilanjutkan dengan suhu diatas $65^{\circ} \mathrm{C}$, granula pati pecah dimana pati akan menyerap air lebih banyak.

\section{KESIMPULAN DAN SARAN}

\section{Kesimpulan}

Studi pembuatan dodol dari buah pisang nangka ini berhasil dengan karakteristik organoleptik yang disukai dari segi rasa dan aroma, tekstur yang kalis serta kadar air sebesar 18,5\%.

\section{Saran}

Lebih lanjut disarankan untuk menganalisa komposisi kimia dodol pisang nangka yang dihasilkan ini meliputi kadar : protein, lemak, gula yang dihitung sebagai sakarosa, serat kasar, cemaran logam dan cemaran mikroba, sehingga dapat ditarik kesimpulan yang menyeluruh apakah produk dodol ini memenuhi persyaratan menyeluruh yang ditetapkan oleh SNI

\section{DAFTAR PUSTAKA}

Anonymous. 1992. Daftar Komposisi Bahan Makanan. Direktorat Gizi, Departemen Kesehatan

Anonymous. 2008. Data Produksi Hortikultura.

Basis Data Pertanian. Departemen

Pertanian.

Http://www.deptan.go.id diakses 8 juni 2008.

Antarlina, SS., H. Dj. Noor, S. Umar dan I. Noor. 2005. Karakteristik Buah Pisang Lahan Rawa Lebak Kalimantan Selatan serta Upaya Perbaikan Mutu Tepungnya. J.Hort. 15(2):140150.

Astawan dan Wahyuni. 1991. Teknologi Pengolahan Pangan Nabati Tepat Guna. IPB Press. Bogor

Imam Muhajir Dasuki, 1989. Pengaruh Suhu Pemeraman Terhadap Perubahan Fisik, Kimia dan Fisiologis Buah Pisang Ambon. Penel.Hort. 3(4): 28-35.

Irawati, R.2001. Pembuatan Dodol Waluh (Kajian Penambahan Tepung Ketan dan Terigu Serta Gula Pasir) Terhadap Sifat Fisik, Kimia dan Organoleptik. Skripsi 
Fakultas Teknologi Pertanian. Stover, R.H \& N.W. Simmonads. 1993. Universitas Brawijaya. Malang Banana. Tropical Agriculture

Rachmi Hatta. 2012. Studi pembuatan dodol dari rumput laut (Eucheuma cottonii)dengan penambahan kacang hijau (Phaseolus eureus). Skripsi Fakultas Teknologi Pertanian. Universitas Hasanuddin. Makasar

Rismunandar. 1990. Bertanam Pisang. C.V. Sinar Baru. Bandung

Rismunandar. 1990. Membudidayakan Tanaman Buah-buahan. C.V. Sinar Baru. Bandung.

Satuhu dan Sunarmani. 2004. Membuat Aneka Dodol Buah. Penebar Swadaya. Jakarta. Series. Longman Scientific ang Technical. New York.

Soenarjono, H. 1998. Teknik Memanen Buah Pisang agar Berkualitas Baik. Trubus no. 341.

Sriharti., Salim, T. 2008. Pemanfaatan Limbah Pisang Untuk Pembuatan Kompos Menggunakan Komposter Rotary Vacum. Balai Besar Pengembangan Teknologi Tepat Guna LIPI. Yogyakarta

Widiastuti, R. 2008. Pemanfaatan Bonggol Pisang Raja Sere (Musa paradisiaca) Se. bagai Bahan Baku pembuatan Cuka. (Skripsi). Fakultas Keguruan. Universitas Muhammadyah Surakarta. Surakarta 